\title{
Dampak pencemaran fishing ground terhadap produksi dan mutu ikan yang tertangkap di Teluk Jakarta
}

\section{The impact of contamination of fishing ground to production and quality of fish caught in Jakarta Bay}

Mustaruddin $^{\mathrm{a}}$, Ernani Lubis ${ }^{\mathrm{a}}$, Ateng Supriatna ${ }^{\mathrm{b}}$, dan Sri S. Kartini ${ }^{\mathrm{c}}$

\author{
${ }^{a}$ Departemen Pemanfaatan Sumberdaya Perikanan, Fakultas Perikanan dan Ilmu Kelautan, Institut Pertanian Bogor, Kampus IPB \\ Darmaga Bogor, 16680, Indonesia [+62-251-8622935] \\ ${ }^{\mathrm{b}}$ Division of Fisheries and Environmental Conservation, Conservation International Indonesia, Jl. Pejaten Barat No.16A Pasar \\ Minggu Daerah Khusus Ibukota Jakarta, 12550, Indonesia \\ ${ }^{\mathrm{c}}$ Praktisi Mutu dan Gizi Hasil Pertanian dan Perikanan, Jl. Mataram Kapling C4 No. 7 Bogor, 16164, Indonesia
}

\section{Article Info: \\ Received: 19 - 03 - 2019 \\ Accepted: 02 - 06 - 2020}

Keywords:

Catch fish, contamination,

fishing ground, $\mathrm{Hg}$, model

Corresponding Author:

Mustaruddin

Departemen Pemanfaatan

Sumberdaya Perikanan, Fakultas

Perikanan dan Ilmu Kelautan,

Institut Pertanian Bogor;

Tel. +62-251-8622935

Email:

mus_m03@yahoo.com

\begin{abstract}
The impact of contamination of fishing ground to production and quality of fish caught in Jakarta Bay. High production and quality of fish are very expected by fishery stakeholders, particularly in Bay Jakarta. However, this can be constraints when the fishing ground is in a contaminated status. The research aims to identify the contaminated status of the fishing ground and operating conditions of fishing, and also to analyze the impact of its contamination on the production and quality of catch fish. These research methods are physics and chemical analysis, diagram Pareto, and model analysis. Research result shows that fishing ground in Bay Jakarta has been contaminated by the aroma, turbidity, garbage, and Hg metal. Fishing operations in the Jakarta bay generally $<5$ GT boat's, lasts 1 until 2 days/trip, with tuna fish, float fish, and swordfish as dominant catches. The results of model analysis show the contamination of fishing ground has degraded significantly the production amount of catch fish in Jakarta Bay $(K P=-0.42$, $P=0.00$ ). The real degradations are in the production of swordfish (a group of demersal fish) and float fish (a group of small pelagic fish). The quality of catch fish also has dropped significantly as an impact by the contamination of fishing ground $(K P=-9.81, P=0.00)$. Quality defects that are clearly troubling fishermen are dirty gills and slimy scales.
\end{abstract}

How to cite (CSE Style $8^{\text {th }}$ Edition):

Mustaruddin, Lubis E, Supriatna A, Kartini SS. 2020. Dampak pencemaran fishing ground terhadap produksi dan mutu ikan yang tertangkap di Teluk Jakarta. JPSL 10(2): 284-293. http://dx.doi.org/10.29244/jpsl.10.2.284-293.

\section{PENDAHULUAN}

Teluk Jakarta adalah wilayah fishing ground yang sempit karena hanya mempunyai luas sekitar $514 \mathrm{~km}^{2}$ dengan kedalaman 5 hingga 10 meter dan mengalami tekanan ekologis pada saat ini karena meningkatnya intensitas pencemaran pada beberapa wilayah perairan yang menjadi fishing ground. Pencemaran fishing ground tersebut umumnya disebabkan oleh kegiatan industri, pemukiman, perkantoran, dan aktivitas jasa di daratan yang membuang limbahmya ke Teluk Jakarta, baik melalui sungai, kanal, maupun pembuangan langsung di pinggir pantai. Hasil penelitian Siregar et al. (2016) dan Mustaruddin (2012) menjelaskan bahwa intensitas pembuangan limbah yang meningkat melalui sungai dan kanal yang bermuara di Teluk Jakarta, telah 
menyulitkan nelayan untuk menemukan fishing ground potensial serta produksi dan mutu ikan yang tertangkap kurang terjamin. Setidaknya ada 13 sungai yang bermuara di Teluk Jakarta tersebut. Sampono et al. (2012) menambahkan bahwa kegiatan reklamasi 14 pulau buatan di Teluk Jakarta juga berkontribusi besar terhadap pencemaran fishing ground dan penurunan mutu ikan yang tertangkap.

Produksi dan mutu ikan asal Teluk Jakarta semakin mengkhawatirkan dan mengancam keberlanjutan mata pencaharian 18686 jiwa nelayan di wilayah Provinsi DKI Jakarta. Dimana sebanyak 10008 jiwa merupakan nelayan lokal, dan sisanya merupakan nelayan pendatang (8678 jiwa) serta sekitar 35\% sampai dengan 40\% dari total nelayan merupakan nelayan skala kecil. Pada tahun 2014, produksi ikan di Teluk Jakarta dan sekitarnya mencapai 11523 ton, naik dibandingkan periode tahun 2010-2013 yang berkisar 7850 sampai dengan 10643 ton, namun turun dibandingkan periode tahun 1990-an (BPS DKI Jakarta, 2016). Sementara itu, menurunnya mutu ikan akan berpengaruh dari tingkat beli konsumen, yang merupakan kalangan industri dan masyarakat Jakarta yang umumnya berdaya beli tinggi dan sangat memperhatikan mutu produk yang dikonsumsi. Menurut BPS DKI Jakarta (2016), mutu berpengaruh paling tinggi terhadap keputusan konsumen Jakarta dalam membeli produk perikanan. Hasil penelitian Levsen dan Karl (2014) menunjukkan bahwa penanganan mutu ikan segar berpengaruh signifikan dalam meningkatkan kepercayaan konsumen terhadap produk perikanan. Untuk itu, penelitian ini bertujuan mengidentifikasi status pencemaran fishing ground dan kondisi operasi penangkapan ikan, serta menganalisis dampak pencemaran tersebut terhadap jumlah produksi dan mutu ikan yang tertangkap. Penelitian ini diharapkan dapat memberikan informasi yang berguna untuk penanganan dampak pencemaran tersebut.

\section{METODE}

\section{Metode Pengumpulan Data}

Jenis data yang dibutuhkan dalam penelitian ini terdiri dari data primer dan data sekunder. Data primer meliputi data karakteristik fisik dan kimia perairan sekitar fishing ground, kondisi operasi penangkapan ikan, serta persepsi pelaku perikanan terhadap produksi dan mutu ikan yang tertangkap. Data sekunder terdiri dari profil nelayan, serta peraturan dan kebijakan perikanan tangkap. Penelitian ini dilakukan pada Januari sampai dengan April 2017.

Data primer terkait karakteristik fisik dan kimia fishing ground dikumpulkan dengan mengambil sampel air laut ditiga lokasi terpilih yang menjadi fishing ground nelayan di Teluk Jakarta, yaitu perairan Pulau Bidadari, Pulau Anyer, dan Pulau Nirwana. Data operasi penangkapan ikan dan sampel ikan dikumpulkan melalui pengamatan langsung dan diskusi terarah kepada nelayan pemilik kapal, yaitu KM. Putra Pratama, KM. Pelangi, KM. Sri Jati, KM. Tiga Suara, dan Ina Laut. Sampel ikan yang diambil adalah ikan yang tertangkap dominan untuk kelompok ikan pelagis besar, ikan pelagis kecil, dan ikan demersal dari tiga fishing ground. Jumlah total sampel ikan mencapai 90 ekor.

Data persepsi pelaku perikanan terkait dampak pencemaran fishing ground terhadap produksi dan mutu ikan yang tertangkap dikumpulkan melalui kuesioner. Pelaku perikanan yang menjadi responden adalah nelayan, pengusaha perikanan, dan staf dari instansi perikanan. Jumlah responden ditetapkan 184 orang mengacu kepada ketentuan analisis SEM untuk metode estimasi maximum likehood, yaitu berkisar 100 hingga 200 orang. Data sekunder, dikumpulkan melalui telaah pustaka terhadap hasil studi dan laporan yang tersedia di PPS Nizam Zachman, Badan Pusat Statistik Provinsi DKI Jakarta, dan perguruan tinggi.

\section{Metode Analisis Data}

Metode analisis yang digunakan dalam penelitian ini terdiri dari analisis fisiko-kimia, diagram pareto, dan analisis model menggunakan SEM. Analisis fisiko-kimia dilakukan untuk menganalisis sampel air laut dari tiga fishing ground terpilih. Parameter yang dianalisis adalah parameter fisiko-kimia yang mengindikasikan pencemaran di fishing ground, seperti total suspended solid (TSS), bau, kekeruhan, warna, suhu, kecepatan arus, sampah, minyak, $\mathrm{pH}$, dissolved oxygen (DO), dan merkuri (Hg) (Maina et al., 2016, Fernández et al., 
2013). Status pencemaran di fishing ground tersebut dapat diketahui melalui hasil analisis yang selanjutnya diperbandingkan dengan baku mutu air laut untuk ikan/biota laut (KLHK, 2004). Analisis diagram pareto dilakukan untuk menentukan tipe cacat mutu dominan, yaitu akumulasi cacat yang sering muncul dengan proporsi berkisar $70 \%$ hingga $80 \%$. Data diagram pareto ini disiapkan melalui uji organopletik terhadap sampel ikan yang tertangkap di fishing ground terpilih. Cacat mutu yang dianalisis diantaranya cacat fisik, bau, sisik berlendir, warna pucat/pudar, insang kotor, dan lembek.

Analisis SEM digunakan untuk menganalisis dampak pencemaran fishing ground terhadap produksi dan mutu ikan yang tertangkap di Teluk Jakarta. Untuk maksud ini, maka semua atribut yang mencirikan komponen utama (pencemaran fishing ground, produksi, dan mutu) diinteraksikan ke dalam model struktural. Tahapan penyusunan dan analisis model struktural tersebut (Santoso, 2011; Mustaruddin, 2009) adalah:

a. Identifikasi dan telaah komponen atribut. Pencemaran fishing ground, komponen atributnya adalah parameter fisiko-kimia dengan status tercemar positif kuat pada fishing ground (diperoleh dari hasil analisis sebelumnya). Komponen atribut untuk produksi ikan dipilih berdasarkan kelompok ikan pelagis besar, ikan pelagis kecil dan ikan demersal yang tertangkap dominan. Komponen atribut untuk mutu ikan yang tertangkap adalah tiga tipe cacat mutu paling dominan yang diduga menjadi dampak pencemaran fishing ground.

b. Perancangan path diagram dan penyusunan persamaan model. Path diagram merupakan rancangan awal model yang dibangun oleh komponen utama dan komponen atributnya. Persamaan model yang dikembangkan ada dua jenis, yaitu (1) measurement model mewakili interaksi komponen utama dengan komponen atribut, dan (2) structural equation mewakili interaksi antar komponen utama.

c. Pengembangan matriks input dan estimasi model. Matriks input yang digunakan adalah matriks kovarian dan matriks korelasi, sedangkan teknik estimasinya adalah matriks likelihood estimation. Teknik ini dipilih karena lingkup interaksi nyata yang dimodelkan termasuk menengah, yaitu Teluk Jakarta.

d. Evaluasi dan interpretasi model. Model struktural yang dikembangkan dan dievaluasi menggunakan kriteria goodness-of-fit (Santoso, 2011). Adapun kriteria goodness-of-fit tersebut adalah chi-square $\left(X^{2}\right)$, probability IFI, TLI, CFI, NFI, dan RMSEA. Standar nilai dari kriteria tersebut adalah masing-masing sekecil mungkin $\geq 0.05, \geq 0.90, \geq 0.80, \geq 0.90, \geq 0.80$, dan $\leq 0.08$. Bila dari hasil evaluasi didapat model struktural dinyatakan sesuai (fit) maka nilai koefisien pengaruh $(\mathrm{KP})$ dan probabilitas pengaruh $(\mathrm{P})$ dari model dapat digunakan untuk interpretasi dampak pencemaran. Dampak dinyatakan signifikan bila mempunyai nilai $\mathrm{P}<0.05$.

\section{HASIL DAN PEMBAHASAN}

\section{Pencemaran Fishing Ground}

Jumlah produksi dan mutu ikan yang tertangkap, tidak lepas dari kondisi fishing ground dimana nelayan melakukan penangkapan ikan. Produksi ikan yang tinggi dan mutu yang baik dapat terjadi bila fishing ground mempunyai karakteristik yang sesuai dengan baku air laut untuk ikan/biota laut. Bila kondisi tersebut tidak terpenuhi, maka terindikasi fishing ground mengalami pencemaran. Fishing ground di Teluk Jakarta diduga mengalami hal tersebut, dan hasil analisisnya disajikan pada Tabel 1.

Berdasarkan Tabel 1, fishing ground di Teluk Jakarta sudah tercemar kuat yang diindikasikan oleh adanya bau, kekeruhan, sampah, dan logam Hg. Pencemaran keempat bahan pencemar ini telah terjadi di semua lokasi, baik fishing ground sekitar Pulau Bidadari, Pulau Anyer, maupun Pulau Nirwana. Bau, sampah, dan logam Hg diduga disebabkan oleh limbah industri, pemukiman, perkantoran, dan aktivitas jasa yang dibuang ke Teluk Jakarta. Menurut Siregar et al. (2016) dan Mustaruddin (2012), ada 13 sungai yang bermuara di Teluk Jakarta yang bagian hulunya sudah tercemar, karena banyak membawa limbah dari wilayah Jakarta dan sekitarnya. Levsen dan Karl (2014) menyatakan bahwa bau dan logam Hg dapat dengan mudah mempengaruhi mutu ikan yang tertangkap. 
Untuk kekeruhan diduga dominan akibat kegiatan reklamasi yang terjadi di Teluk Jakarta. Hal ini terlihat dari tingginya nilai kekeruhan pada fishing ground sekitar Pulau Bidadari (dekat dengan kawasan reklamasi), yaitu mencapai 8.2 NTU. Menurut Sampono et al. (2012), perairan sekitar Pulau Bidadari merupakan satu dari empat lokasi pengerukan pasir laut dan lalu lintas kapal tongkang yang digunakan dalam reklamasi. Fishing ground Teluk Jakarta juga tercemar oleh minyak dan TSS, namun belum menyebar di semua lokasi. Minyak dan TSS tersebut dominan berasal dari limbah industri, aktivitas kapal, dan jasa di pelabuhan (Sindern et al., 2016), dimana pencemarannya di Teluk Jakarta sudah melebihi kemampuan asimilasi lingkungan (Firmansyah et al., 2012). Tingkat pembuangan pada level tertentu dapat menyebabkan akumulasi bahan pencemar pada ikan dan organisme akuatik lainnya. Hasil akhir yang mungkin terjadi adalah imunosupresi, metabolisme berkurang, dan kerusakan insang dan epitel (Austin, 1998). Selanjutnya dikatakan bahwa dugaan penyakit yang berhubungan dengan polusi adalah papiloma epidermal, busuk sirip/ekor, penyakit insang, hiperplasia, kerusakan hati, neoplasia dan ulserasi.

Tabel 1 Status pencemaran fishing ground

\begin{tabular}{lccccc}
\hline \multirow{2}{*}{ Parameter } & \multirow{2}{*}{ Baku Mutu* } & \multicolumn{3}{c}{ Fishing ground } & \multirow{2}{*}{ Status Pencemaran } \\
\cline { 3 - 5 } & & FG1 & FG2 & FG3 & Positif \\
TSS (ppm) & 25 & 26.2 & 25.2 & 24.4 & Positif kuat \\
Bau & Alami (-) & ++ & + & + & Positif kuat \\
Kekeruhan (NTU) & $<5$ & 8.2 & 6.7 & 5.1 & Negatif \\
Warna (CU) & $<50$ & 45 & 36 & 24 & Negatif \\
Suhu $\left({ }^{\circ}\right.$ C) & Alami & 32.1 & 30.4 & 29.2 & Negatif \\
Kecepatan arus & $<2$ & 1.12 & 1.25 & 1.36 & Positif kuat \\
(m/detik) & & & & & Positif \\
Sampah & Tidak Ada (-) & ++ & ++ & + & Negatif \\
Minyak & $<1$ & 1.2 & 0.92 & 0.14 & Negatif \\
pH & $6-9$ & 7.3 & 6.6 & 7.1 & Positif kuat \\
DO (ppm) & $>4$ & 5.1 & 6.2 & 6.4 & \\
Logam Hg (ppm) & $<0.002$ & 0.012 & 0.011 & 0.007 & . \\
\hline
\end{tabular}

Keterangan: (1) *KLHK (2004), (2) FG1, FG2, dan FG3 berturut-turut adalah fishing ground di sekitar pulau bidadari, pulau anyer, dan pulau nirwana

\section{Operasi Penangkapan Ikan}

Dalam konteks pengembangan perikanan, kegiatan industri, reklamasi, lalu lintas pelayaran, dan lainnya yang dilakukan berdekatan dengan kawasan fishing ground dapat secara serius mengganggu operasi penangkapan ikan. Tabel 2 memperlihatkan kondisi teknis operasi penangkapan ikan di Teluk Jakarta.

Tabel 2 Kondisi teknis operasi penangkapan ikan di Teluk Jakarta

\begin{tabular}{lcccc}
\hline \multicolumn{1}{c}{ Kapal Ikan } & ABK (orang) & $\begin{array}{c}\text { Jumlah } \\
\text { Hari } \\
\text { Operasi } \\
\text { (hari/trip) }\end{array}$ & $\begin{array}{c}\text { Produksi Rata-Rata } \\
(\mathrm{kg} / \text { trip })\end{array}$ & Ikan yang Tertangkap Dominan \\
\hline KM. Putra Pratama & 8 & 2 & 215 & tongkol, layang, tembang \\
KM. Pelangi & 3 & 1 & 35 & tongkol, manyung, layur \\
KM. Sri Jati & 3 & 1 & 23 & tongkol, laying \\
KM. Tiga Suara & 6 & $1-2$ & 146 & tongkol, laying \\
Ina Laut & 4 & 1 & 41 & layur, cakalang, ekor kuning \\
\hline
\end{tabular}


Operasi penangkapan ikan di Teluk Jakarta umumnya menggunakan kapal berukuran <5 GT, dengan jumlah hari operasi 1 sampai 2 hari/trip. Bila dihubungkan dengan jumlah produksi ikan dan ABK yang terlibat, maka kinerja operasi penangkapan ini tidak begitu menggembirakan. KM. Sri Jati misalnya, rata-rata hanya mendapatkan $23 \mathrm{~kg}$ ikan selama 1 hari operasi/trip dengan diikuti $3 \mathrm{ABK}$. Dari informasi nelayan, setelah dikeluarkan biaya operasional, maka bagi hasil untuk mereka hanya 25000 hingga 30000 rupiah per orang. Hal yang sama juga untuk KM. Pratama yang diikuti oleh 8 ABK dalam 2 hari operasi/trip dan Ina laut yang dikuti oleh 4 ABK dalam 1 hari operasi/trip. Mustaruddin (2012) menyatakan bahwa penyempitan fishing ground merupakan penyebab utama dari menurunnya produksi ikan di Teluk Jakarta. Hal ini terus terjadi seiring dengan meningkatnya kegiatan reklamasi, padatnya jalur pelayaran, dan pencemaran perairan oleh aktivitas manusia di daratan.

Jenis ikan yang tertangkap dominan berbeda-beda untuk setiap kapal ikan, namun yang paling banyak ditangkap adalah tongkol, layang, dan layur. Ketiga jenis ikan ini dapat saja terkena dampak dari pencemaran fishing ground, meskipun penanganan mutu telah dilakukan dengan baik. Sampono et al. (2002) menyatakan bahwa bahan pencemar dalam bentuk padatan tersuspensi, sampah, dan minyak yang termakan atau menempel pada tubuh ikan relatif sulit dihilangkan, meskipun pembersihan sudah dilakukan sejak ikan di atas kapal.

\section{Dampak Pencemaran Fishing Ground terhadap Produksi dan Mutu Ikan yang Tertangkap}

\section{Hasil Analisis Model}

Dampak pencemaran fishing ground terhadap jumlah produksi dan mutu ikan yang tertangkap dianalisis menggunakan pendekatan model struktural (SEM). Bila mengacu kepada metodologi, komponen atribut pencemaran fishing ground (CEM-FG) dipilih dari parameter fisiko-kimia yang tercemar positif kuat, dimana berdasarkan hasil analisis sebelumnya, parameter tersebut adalah bau (X1), kekeruhan (X2), sampah (X3), dan logam Hg (X4). Pemilihan parameter seperti ini dimaksudkan supaya lebih terlihat konsistensi antara jenis bahan pencemar yang timbul dengan yang diukur dampaknya. Santoso (2011), menyatakan bahwa konsistensi logis yang terbangun dalam interaksi model menjadi bagian penting dari konfirmasi teori yang dapat meningkatkan validitas struktur dari model.
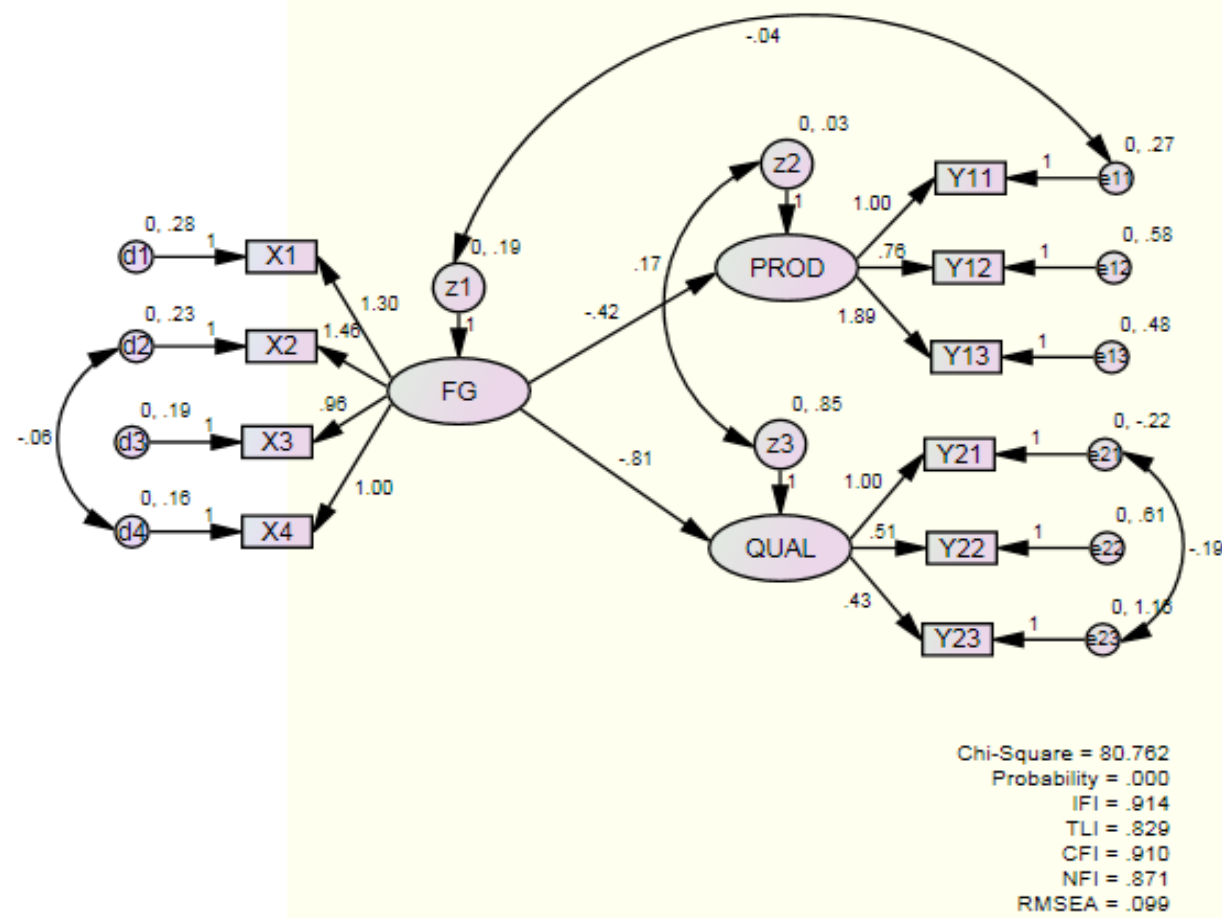

Gambar 1 Model struktural analisis dampak pencemaran fishing ground terhadap produksi dan mutu ikan yang tertangkap di Teluk Jakarta 
Untuk produksi (PROD), komponen atributnya merepresentasikan kelompok ikan yang tertangkap, yaitu tongkol (Y11) mewakili ikan pelagis besar, layang (Y12) mewakili ikan pelagis kecil, dan layur (Y13) mewakili ikan demersal. Ketiga jenis ikan tersebut merupakan yang paling banyak tertangkap di Teluk Jakarta (Tabel 2). Komponen atribut dari mutu ikan yang tertangkap (QUAL) dipilih dari cacat mutu dominan berdasarkan hasil analisis pareto, yaitu bau (Y21), insang kotor (Y22), dan sisik berlendir (Y23). Batista et al. (2015), juga Levsen dan Karl (2014) menyatakan bahwa cacat mutu pada ikan yang tertangkap berkomparasi signifikan dengan kondisi fishing ground, metode penangkapan, dan ketahanan ikan selama masa pertumbuhan (larva). Model struktural analisis dampak pencemaran fishing ground terhadap jumlah produksi dan mutu ikan yang tertangkap secara lengkap disajikan pada Gambar 1.

Untuk mengetahui apakah model tersebut sudah memenuhi kriteria goodness-of-fit yang dipersyaratkan, maka hasil evaluasinya disajikan pada Tabel 3.

Tabel 3 Hasil evaluasi kesesuaian model dengan kriteria goodness-of-fit

\begin{tabular}{cccc}
\hline Kriteria goodness-of-fit & Standar Nilai* & Kinerja Model** & Keterangan \\
\hline Chi-square $\left(X^{2}\right)$ & Sekecil mungkin & 80.762 & Baik \\
Probability & $\geq 0.05$ & 0.000 & Cukup baik \\
IFI & $\geq 0.90$ & 0.914 & Baik \\
TLI & $\geq 0.80$ & 0.829 & Baik \\
CFI & $\geq 0.90$ & 0.910 & Baik \\
NFI & $\geq 0.80$ & 0.871 & Baik \\
RMSEA & $\leq 0.08$ & 0.099 & Cukup baik \\
\hline
\end{tabular}

*Santoso (2011), **hasil analisis model (2017)

Berdasarkan Tabel 3, semua kriteria goodness-of-fit yang dipersyaratkan dapat dipenuhi oleh model struktural yang dikembangkan. Hal ini berarti bahwa model tersebut sudah mencerminkan data yang ada dan tidak ada perbedaan antara matriks kovarian data dengan matriks yang diestimasi. Terkait dengan ini, maka model struktural tersebut sudah sesuai (fit) dan dapat digunakan untuk menjelaskan dampak pencemaran fishing ground terhadap jumlah produksi dan mutu ikan yang tertangkap di Teluk Jakarta.

\section{Dampak Pencemaran Fishing Ground terhadap Produksi Ikan}

Berdasarkan Gambar 1, bahan pencemar yang berkontribusi signifikan terhadap pencemaran fishing ground di Teluk Jakarta adalah bau (X1), kekeruhan (X2), dan sampah (X3). Hal ini ditunjukkan oleh nilai koefisien pengaruh (KP) yang tinggi, yaitu masing-masing 1.30, 1.46 dan 0.96 dengan probabilitas $(\mathrm{P})<0.05$, yaitu 0.00. Menurut Siregar et al. (2016), bau pada air laut Teluk Jakarta merupakan sumbangan dari limbah cair industri, pemukiman, dan aktivitas jasa, sedangkan menurut Cerveny et al. (2014), limbah cair dari aktivitas manusia lebih mudah mencemari perairan, karena sebagian besar tersusun oleh komponen organik yang mudah busuk. Sampah umumnya berasal dari bahan kemasan, potongan kayu, dan material bangunan.

Pengaruh logam Hg belum terasa nyata $(\mathrm{P}>0.05)$, meskipun mempunyai nilai KP yang tinggi. Hal ini bisa jadi karena sifat logam berat yang mengakumulasi pada komponen perairan dengan pengaruh yang baru terlihat setelah waktu cukup lama. Sindern et al. (2016) dan Mustaruddin (2012) menyatakan bahwa logam berat yang ikut termakan oleh manusia ketika mengkonsumsi ikan, akan terasa jelas dampaknya di usia tua atau pada generasi berikutnya. Tabel 4 menyajikan hasil analisis dampak pencemaran fishing ground terhadap jumlah produksi ikan di Teluk Jakarta.

Dalam kaitan dengan jumlah produksi, hasil analisis model menunjukkan bahwa secara langsung, pencemaran fishing ground dapat menurunkan jumlah produksi ikan di Teluk Jakarta. Hal ini ditunjukkan oleh nilai KP yang negatif, yaitu -0.42 (Tabel 4). Dampak penurunan tersebut juga signifikan mengganggu kegiatan nelayan dan pengusaha perikanan (nilai $\mathrm{P}<0.05$, yaitu 0.00). Menurut Batista et al. (2015) dan Cerveny et al. 
(2014), fishing ground yang tercemar dapat mengganggu perkembangbiakan ikan, dan bila operasi penangkapan ikan dilakukan, akan menjadi tidak efektif (produksi rendah). Hasil analisis sebelumnya (Tabel 2) juga menunjukkan jumlah produksi yang rendah di Teluk Jakarta.

Tabel 4 Dampak pencemaran fishing ground terhadap jumlah produksi ikan

\begin{tabular}{ccccccc}
\hline \multicolumn{2}{c}{ Interaksi Komponen } & KP & S.E. & C.R. & P & Label \\
\hline PROD & CEM-FG & -0.42 & 0.12 & -3.43 & 0.00 & par_6 \\
Y11 & PROD & 1.00 & & & fix & \\
Y12 & PROD & 0.76 & 0.25 & 3.07 & 0.002 & par_4 \\
Y13 & PROD & 1.89 & 0.42 & 4.53 & 0.00 & par_5 \\
\hline
\end{tabular}

Keterangan: $\mathrm{PROD}=$ jumlah produksi, $\mathrm{CEM}-\mathrm{FG}=$ pencemaran fishing ground, $\mathrm{Y} 11=$ tongkol, $\mathrm{Y} 12=$ layang, dan Y13 = layur

Bila dampak pencemaran ditinjau berdasarkan kelompok ikan, maka penurunan jumlah produksi yang tinggi dan nyata terjadi pada ikan layur/kelompok ikan demersal (Y13) $(\mathrm{KP}=1.89$ dan $\mathrm{P}=0.00)$. Hal ini diduga karena ikan demersal bergerak pasif dan mempunyai habitat di dasar perairan (Y12). Marchal et al. (2014) menyatakan bahwa pola migrasi yang relatif pasif dengan jangkauan yang sempit menjadi penyebab utama kelompok ikan ini mudah terkena dampak jika terjadi destruksi fishing ground. Penurunan jumlah produksi yang nyata juga terjadi pada ikan layang (Y11/kelompok ikan pelagis kecil), namun dengan pola yang lebih rendah $(\mathrm{KP}=0.76)$. Pola penurunan produksi yang rendah terjadi karena ada time lag sebagai akibat dari kemampuan migrasi terbatas ikan pelagis kecil (Biasane et al., 2012). Ikan tongkol (Y13/kelompok ikan pelagis besar), penurunan produksinya tidak signifikan $(\mathrm{P}=$ fix $)$. Hal ini kemungkinan disebabkan oleh pola migrasi ikan tongkol yang aktif, sehingga lebih mudah menghindar bila ada gangguan bahan pencemar. Tamarol dan Wuaten (2013) menyatakan bahwa pergerakan ikan pelagis besar bisa mencapai $<1000 \mathrm{~km}$ setiap bulannya tergantung kondisi perairan. Coelho et al. (2015) menambahkan bahwa pergerakan aktif juga dibutuhkan secara alami oleh ikan pelagis besar untuk berespirasi. Dalam konteks produksi, hal ini berkontribusi besar untuk meningkatkan bobot dan mutu ikan pada saat ditangkap.

\section{Dampak Pencemaran Fishing Ground terhadap Mutu Ikan yang Tertangkap}

Ikan yang tertangkap sangat mungkin mengalami cacat mutu bila terdapat bahan pencemar yang berlebihan di fishing ground. Hal ini karena bahan pencemar tersebut mengganggu pertumbuhan ikan dan mempunyai sifat mengontaminasi produk perikanan. Gambar 2 menyajikan diagram Pareto untuk analisis tipe cacat mutu dominan pada ikan yang tertangkap di Teluk Jakarta.

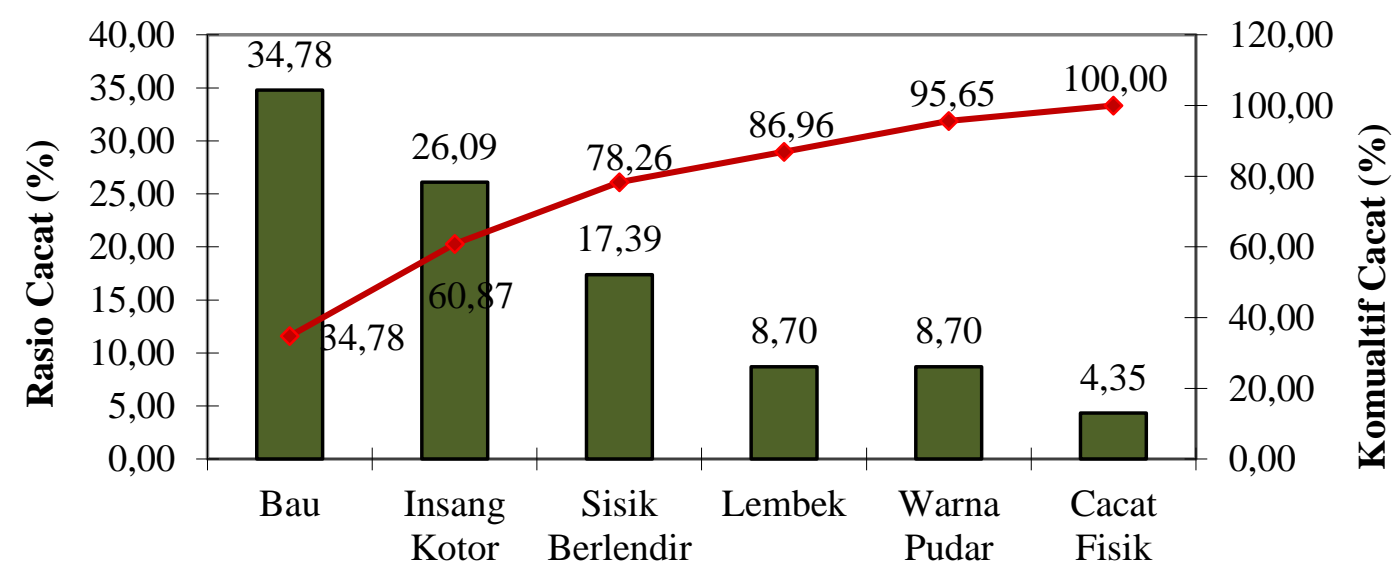

Gambar 2 Diagram pareto tipe cacat mutu dominan pada ikan yang tertangkap 
Berdasarkan Gambar 2, cacat yang dominan terjadi pada ikan yang tertangkap adalah bau (34.78\%), insang kotor (26.09\%), dan sisik berlendir (17.39\%). Proporsi ketiga tipe cacat ini berada dalam kisaran 70\% hingga $80 \%$, yaitu 78.26\%. Hasil analisis model (Tabel 5) menunjukkan seberapa besar dampak pencemaran fishing ground mempengaruhi mutu ikan yang tertangkap.

Tabel 5 Dampak pencemaran fishing ground terhadap mutu ikan yang tertangkap

\begin{tabular}{|c|c|c|c|c|c|c|c|}
\hline \multicolumn{3}{|c|}{ Interaksi Komponen } & $\mathrm{KP}$ & S.E. & C.R. & $\mathrm{P}$ & Label \\
\hline QUAL & $\longleftarrow$ & CEM-FG & -0.81 & 0.16 & -4.98 & 0.00 & par_9 \\
\hline Y21 & 4 & QUAL & 1.00 & & & fix & \\
\hline Y22 & $\longleftarrow$ & QUAL & 0.51 & 0.09 & 5.63 & 0.00 & par_7 \\
\hline Y23 & 4 & QUAL & 0.43 & 0.12 & 3.48 & 0.00 & par_8 \\
\hline
\end{tabular}

Keterangan: QUAL = mutu ikan yang tertangkap, $\mathrm{CEM}-\mathrm{FG}=$ pencemaran fishing ground, $\mathrm{Y} 21=\mathrm{bau}, \mathrm{Y} 12=$ insang kotor, dan Y13 = sisik berlendir.

Berdasarkan Tabel 5 tersebut, pencemaran fishing ground di Teluk Jakarta dapat secara langsung menurunkan mutu ikan yang tertangkap. Hal ini ditunjukkan oleh nilai koefisien pengaruh (KP) yang negatif, yaitu -0,81. Penurunan mutu tersebut termasuk signifikan karena sudah meresahkan para pelaku perikanan di Teluk Jakarta $(\mathrm{P}<0.05$, yaitu 0.00). Gómez-Sala et al. (2016) menyatakan bahwa mutu produk perikanan termasuk ikan segar yang baru ditangkap sangat mudah terkontaminasi bila ada bahan pencemar yang mengotorinya. Menurut Levsen dan Karl (2014), hal ini bisa terjadi karena daging ikan tersusun oleh komponen organik yang mudah bereaksi secara enzimatis, terutama bila kondisinya basah/berair.

Bila dampak pencemaran dikaji lebih jauh berdasarkan tipe cacat dominan, maka ada kecenderungan semakin banyak bahan pencemar, maka semakin mudah ditemukan ikan yang tertangkap dengan kondisi berbau/Y21 (KP = 1.00), insang kotor/Y22 ( $\mathrm{KP}=0.51)$, dan sisik berlendir/Y23(KP = 0.43). Dari ketiga tipe cacat mutu tersebut, insang kotor dan sisik berlendir telah secara nyata meresahkan pelaku perikanan. Hal ini ditunjukkan oleh nilai $\mathrm{P}<0.05$, yaitu masing-masing 0.00 . Kedua tipe cacat mutu ini dominan karena kekeruhan tinggi (kaya komponen amoniak) dan banyaknya sampah yang dibuang ke perairan (Mustaruddin et al., 2018) dan kondisi ini terjadi di Teluk Jakarta seperti ditunjukkan pada Tabel 1. Khusus kekeruhan, sangat mudah mencemari karena sifatnya yang tersuspensi atau melayang-layang di perairan (Siregar et al., 2016). Sindern et al. (2016) dan Cerveny et al. (2014), menyatakan bahwa sisik dengan lendir tidak wajar juga dapat disebabkan oleh koagulasi komponen logam dari perairan.

Cacat mutu dalam bentuk bau pada ikan yang tertangkap belum mencapai taraf serius ( $\mathrm{P}=$ fix $)$, meskipun perairan di ketiga fishing ground mempunyai bau yang tidak alami (tercemar positif kuat). Hal ini bisa jadi karena komponen bau tersebut banyak mengandung komponen volatil, sehingga lebih mudah menguap. Levsen dan Karl (2014) serta Gómez-Sala et al. (2016), menjelaskan bahwa kedekatan fishing ground dengan fishing base memberi keuntungan tersendiri bagi pelaku perikanan dalam menjaga mutu ikan yang tertangkap dan mengurangi reaksi pembusukan secara organik.

\section{KESIMPULAN}

Perairan di sekitar fishing ground Teluk Jakarta tercemar kuat oleh bau, kekeruhan, sampah, dan logam Hg. Operasi penangkapan ikan di Teluk Jakarta umumnya menggunakan kapal $<5$ GT, berlangsung 1 sampai dengan 2 hari/trip, dengan hasil tangkapan dominan berupa ikan tongkol, layang, dan layur. Pencemaran fishing ground telah secara signifikan menurunkan jumlah produksi ikan di Teluk Jakarta $(\mathrm{KP}=-0.42, \mathrm{P}=$ 0.00). Penurunan tersebut terlihat nyata pada produksi ikan layur/kelompok ikan demersal $(\mathrm{KP}=1.89, \mathrm{P}=$ $0.00)$ dan ikan layang/kelompok ikan pelagis kecil $(\mathrm{KP}=0.76, \mathrm{P}=0.00)$. Mutu ikan yang tertangkap juga turun secara signifikan akibat pencemaran fishing ground di Teluk Jakarta $(\mathrm{KP}=-0.81, \mathrm{P}=0.00)$. Cacat mutu 
yang secara nyata meresahkan pelaku perikanan adalah insang kotor $(\mathrm{KP}=0.51, \mathrm{P}=0.00)$ dan sisik berlendir $(\mathrm{KP}=0.43, \mathrm{P}=0.00)$.

\section{DAFTAR PUSTAKA}

[BPS] Badan Pusat Statistik Provinsi DKI Jakarta. 2016. Statistik Produksi Perikanan Tangkap DKI Jakarta Menurut Lokasi Periode Tahun 2010-2014. Jakarta (ID): Badan Pusat Statistik.

[KLHK] Kementerian Negara Lingkungan Hidup. 2004. Keputusan Menteri Negara Lingkungan Hidup No. 51 Tahun 2004 tentang Baku Mutu Air Laut untuk Biota Laut. Kementerian Negara Lingkungan Hidup. Jakarta.

Austin B. 1998. The Effects of pollution on fish health. Journal of Applied of Microbiology. 85(1): 234S-242S. doi: https://doi.org/10.1111/j.1365-2672.1998.tb05303.x.

Batista MI, Horta e Costa B, Gonçalves L, Henriques M, Erzini K, Caselle JE, Gonçalves EJ, Cabral HN. 2015. Assessment of catches, landings and fishing effort as useful tools for MPA management. Journal of Fisheries Research. 172(1): 197-208. doi: https://doi.org/10.1016/j.fishres.2015.07.020.

Biasane AN, Fauzi A, Monintja DR, Soedharma D. 2012. Pengelolaan perikanan pelagis kecil berbasis daya dukung lingkungan perairan di Kepulauan Sangihe. Jurnal Pengelolaan Sumberdaya Alam dan Lingkungan. 2(1): 37-45. doi: https://doi.org/10.29244/ jps1.2.1.37.

Cerveny D, Zlabek V, Velisek J, Turek J, Grabic R, Grabicova K, Fedorova G, Rosmus J, Lepic P, Randak T. 2014. Contamination of fish in important fishing grounds of the Czech Republic. Journal of EES. 109(1): 101-109. https://doi.org/10.1016/j.ecoenv. 2014.07.034.

Coelho R, Fernandez-Carvalho J, Santos MN. 2015. Habitat use and diel vertical migration of bigeye thresher shark: Overlap with pelagic longline fishing gear. Journal of Marine Environmental Research. 112(2): 91-99. doi: https://doi.org/10.1016/j.marenvres.2015. 10.009.

Fernández N, Fernández-Boán M, Verísimo P, Freire J. 2013. Assessing the spatial variability, level and source of organic chemical contaminants in bivalve fishing grounds on the Galician coast. Marine Pollution Bulletin. 71(1): 291-301. doi: https://doi.org/ 10.1016/j.marpolbul.2013.06.038.

Firmansyah I, Riani E, Kurnia R. 2012. Model pengendalian pencemaran laut untuk meningkatkan daya dukung lingkungan Teluk Jakarta. Jurnal Pengelolaan Sumberdaya Alam dan Lingkungan. 2(1): 22-28. doi: https://doi.org/10.29244/ jpsl.2.1.22.

Gómez-Sala B, Herranz C, Díaz-Freitas B, Hernández PE, Sala A, Cintas LM. 2016. Strategies to increase the hygienic and economic value of fresh fish: Biopreservation using lactic acid bacteria of marine origin. Journal of Food Microbiology. 223(1): 41-49. doi: https://doi.org/10.1016/j.ijfoodmicro.2016.02.005.

Levsen A, Karl H. 2014. Anisakis simplex (s.1.) in grey gurnard (Eutrigla gurnardus) from the north sea: Food safety considerations in relation to fishing ground and distribution in the flesh. Journal of Food Control. 36(1) : 15-19. doi: https://doi.org/10.1016/ j.foodcont.2013.07.006.

Maina I, Kavadas S, Katsanevakis S, Somarakis S, Tserpes G, Georgakarakos S. 2016. A methodological approach to identify fishing grounds: A case study on Greek trawlers. Journal of Fisheries Research. 183(1): 326-339. doi: https://doi.org/10.1016/ j.fishres.2016.06.021.

Marchal P, Desprez M, Vermard Y, Tidd A. 2014. How do demersal fishing fleets interact with aggregate extraction in a congested sea?. Journal of Estuarine, Coastal and Shelf Science. 149(1): 168-177. doi: https://doi.org/10.1016/j.ecss.2014.08.005.

Mustaruddin, Wiyono ES, Khotib M, Asnil, Bahri S. 2018. Pola pencemaran lokasi penangkapan dan ikan hasil tangkapan akibat berkembangnya aktivitas ekonomi di sekitar Danau Maninjau. Jurnal Pengelolaan Sumberdaya Alam dan Lingkungan. 8(2): 134-142. doi: https://doi.org/10.29244/jpsl.8.2.134-142.

Mustaruddin. 2009. Pola pengembangan industri perikanan tangkap di kabupaten indramayu menggunakan pendekatan analisis persamaan struktural. Buletin PSP. 18(2): 103-114. 
Mustaruddin. 2012. Pola pencemaran $\mathrm{Hg}$ dan $\mathrm{Pb}$ pada fishing ground dan ikan yang tertangkap nelayan: Studi kasus di Teluk Jakarta. Bumi Lestari. 13(2): 214-224.

Sampono N, Purbayanto A, Haluan J, Fauzi A, Wiryawan B. 2012. Dampak reklamasi Teluk Jakarta terhadap kegiatan penangkapan ikan di Teluk Jakarta. Jurnal Perikanan dan Kelautan. 2(2): 105-112.

Santoso S. 2011. Structural Equation Modeling (SEM), Konsep dan Aplikasinya dengan AMOS 18. Jakarta (ID): Penerbit PT Elex Media Komputindo.

Sindern S, Tremöhlen M, Dsikowitzky L, Gronen L, Schwarzbauer J, Siregar TH, Ariyani F, Irianto HE. 2016. Heavy metals in river and coast sediments of the Jakarta Bay region (Indonesia). Marine Pollution Bulletin. 110(2) : 624-633. doi: https://doi.org/10.1016/ j.marpolbul.2016.06.003.

Siregar TH, Priyanto N, Putri AK, Rachmawati N, Triwibowo R, Dsikowitzky L, Schwarzbauer J. 2016. Spatial distribution and seasonal variation of the trace hazardous element contamination in Jakarta Bay, Indonesia. Marine Pollution Bulletin. 110(2): 634-646.

Tamarol J, Wuaten JF. 2013. Daerah penangkapan ikan tuna (Thunnus sp.) di Sangihe, Sulawesi Utara. Jurnal Perikanan dan Kelautan Tropis. 9(2): 54-59. doi: https://doi.org/10.35800/jpkt.9.2.2013.4172. 